\title{
Flotation and Enhanced Spectrophotometric Determination of Uranium (VI) in Environmental Samples
}

\author{
Magda A. Akl* and Rabeaa A. N. Masoud \\ ${ }^{*}$ Chemistry Department, Faculty of Science, Mansoura University, Mansoura, Egypt.
}

\begin{abstract}
A GREEN and simple technique for the separation via flotation and spectrophotometric detection of U(VI) in water and real ore samples is presented in this research study in which the heterocyclic azo dye 4-(2pyridyl azo) resorcinol (NaPAR) is used to preconcentrate the uranyl(VI) ions to form a reddish complex in the aqueous solution in the $\mathrm{pH}$ range 5.0.6.0. The oleic acid (HOL) surfactant was used to float the formed 1:1 U(VI):NaPAR complex successfully and completely to the scum layer. The physicochemical characteristics of the proposed analytical technique have been determined. Under optimum parameters, the following physicochemical characteristics were obtained. Beer's law was obeyed up to 300 $\mu \mathrm{g} 1^{-1}$, the correlation coefficient $\left(\mathrm{R}^{2}\right)$ was calculated to be $\mathrm{R}^{2}=0.9995$. According to IUPAC recommendations, the limit of detection (LOD) and limit of quantification (LOQ) are 0.9 and $3.1 \mu \mathrm{g} \mathrm{l}^{-1}(\mathrm{n}=5)$, respectively. The molar absorptivity $(\mathcal{E})$ is $0.63 \times 10^{6} 1 \mathrm{~mol}^{-1} \mathrm{~cm}^{-1}$ in the scum layer with a preconcentration factor 100 and the RSD $(n=5)$ is $2.5 \%$. Excess amount of the chelating agent NaPAR was used to mask the effects of diverse ions on the flotation efficiency. The proposed procedure was applied to determine U(VI) in water samples as well as in U-Th and granite ore samples. The separation mechanism is explained.
\end{abstract}

Keywords: U(VI), Spectrophotometry, flotation, oleic acid, Surfactants-complex formation, $\mathrm{U}-\mathrm{Th}$ and granite ores

\section{Introduction}

Uranium was the first radioactive element to be discovered and is one of the main natural nuclides in biogeochemical studies and environment monitoring [1]. The U-series nuclides are already traditionally used to judge biogeochemical procedures, including dynamic processes concerning sediments, vertical and horizontal diffusion procedures and submarine groundwater effluents [2]. The uranium concentration within the oceans is rather constant at about $3.3 \mathrm{mg} / \mathrm{kg}$ $[3,4]$ and the average amount of uranium in river waters is approximately $1.3 \mathrm{nmol} / \mathrm{kg}$ [5].

Uranium content of land waters (Fresh water flowing over the land; flood water; the water of lakes, rivers, springs, etc., as opposed to seawater) more than $1 \mathrm{ppb}$ is considered abnormal. This extreme dilution in the existence of relatively high concentration of other ions causes it to be hard to determine directly and delicate analytical techniques have to be used to determine trace amounts [6].
Various techniques for the determination of total uranium are reported including voltammetry [7], polarography [8], fluorimetry [9, 10], X-ray fluorescence spectroscopy (XRF) [11], spectrophotometry [12-15], and ICP spectroscopy $[16,17]$. Separation and preconcentration techniques tend to be employed just before analysis. Solvent extraction [18-20] and ion exchange $[21,22]$ are popular methods because of their applicability to both preconcentration and separation.

Various routes for the spectrophotometric determination of uranium depending on the utilization of balmic acid, morin, sodium fluoride, pyrogallol red, pyrogallic acid etc., are already reported [23], but a lot of them demands a liquid-liquid extraction step and entail many disadvantages regarding reproducibility, simplicity, rapidity and sensitivity.

The heterocyclic azo substances are sensitive important chromogenic and complexing agents. These dyes happen to be beneficial in the spectrophotometric determination because of

* Corresponding author e-mail: magdaak1@yahoo.com 
their good selectivity and sensitivity over a large range $\mathrm{pH}$ and since they>re not too difficult to synthesize and purify.

Flotation techniques are already extensively employed for determination of trace heavy metals in media of diverse origin. [24-36] Flotation has attracted significant attention as it simply matches the «Green Chemistry» principle, as the quantity of organic solvent is far small compared to that is used in the traditional liquid-liquid extraction.

Spectrophotometry is still considered as a good instrumental method of analysis for the determination of heavy metals in water samples because it is simple, of low-cost and is conveniently available [37].

The objective of the present study is to provide an easy, rapid and economical flotation- spectrophotometric method for microdetermination of uranyl (VI) in water and real ore samples using the heterocyclic azo dye 4-(2-pyridylazo)-resorcinol, (NaPAR) as a chelating reagent and the oleic acid (HOL) as a surfactant. Also, the effects of the foreign ions were studied.

\section{Experimental}

\section{Instruments}

The flotation cells used in this study have previously been described [24]. Flotation cell (a) is a cylindrically graduated glass tube of 16 $\mathrm{mm}$ inner diameter and $290 \mathrm{~mm}$ length with a stopcock at the bottom. Such cell is used to study the different factors affecting the efficiency of flotation. Flotation cell (b) is a cylindrical tube of $6 \mathrm{~cm}$ inner diameter and $45 \mathrm{~cm}$ length with a stop cock at the bottom and a quick fit stopper at the top. This cell is used to separate cobalt from 1 liter of different water samples. Unicam UV/ Vis spectrometers were used to record the spectral data. Digital $\mathrm{pH}$ meters were used to measure the $\mathrm{pH}$ values of sample solutions.

\section{Chemicals}

The chemicals used in this study are all of analytical reagent grade. Double distilled water (DDW) was used. To prepare uranium stock solution (1000 $\mathrm{mg} / \mathrm{L}), 0.89095 \mathrm{~g}$ of $\mathrm{UO}_{2}\left(\mathrm{CH}_{3} \mathrm{COO}\right)_{2} \cdot \mathrm{H}_{2} \mathrm{O}$ was dissolved in 100 milliliters of water in the presence of 2 milliliters of concentrated $\mathrm{HCl}$ and is diluted to $0.5 \mathrm{~L}$ with DDW. Oleic acid was obtained from Sigma. Oleic acid (HOL) stock solution; 6.03 $\times 10^{-2}$ moll- $^{-1}$, has been prepared [24]. Stock solution of NaPAR,
$0.01 \mathrm{moll}^{-1}$ was prepared by dissolving $0.255 \mathrm{gm}$ of 4-(2-pyridyl azo)-resorcinol monosodium salt in $100 \mathrm{ml}$ of DDW. Five certified ore samples, known as U-Th ore (206 ADL 1A), U-Th ore (206 ADH 1A), U ore (206 ABL 2A), granite (I) (MALI MINTEK GRANITE: NIM. G.) and granite(II) (83 MALS MINTEK LUJAVRITE NJM.I.) were obtained from the National Institute of Metallurgy, South Africa and were used to conduct this study.

\section{Analytical procedure}

Defined amount (specified for each investigation) of both the analyte U(VI) and the reagent (NaPAR) were mixed. Acetate buffer was used to adjust the $\mathrm{pH}$ of mixture to 6 . The mixture was then taken totally to the flotation cell (type a) and completed to $20 \mathrm{ml}$ with DDW. The cell was shaken well for few seconds. $3 \mathrm{ml}$ of $2 \times 10^{-}$ ${ }^{4} \mathrm{~mol} \mathrm{l}^{-1} \mathrm{HOL}$, were added, to this solution. The flotation cell was then inverted upside down for few minutes by hand. After $5 \mathrm{~min}$, to ascertain that flotation is completed, the concentration of the U(VI) ion in the scum layer was determined spectrophotometrically at $\lambda_{\max } 530$.

The floatability (F, \%), of U(VI) was determined using the relation:

$\mathrm{F}=\left\{\mathrm{C}_{\mathrm{S}} / \mathrm{C}_{\mathrm{i}}\right\} \times 100 \%$

Where $C_{i}$ and $C_{s}$ are the initial and scum concentrations of the analyte, respectively.

\section{Results and Discussion}

\section{Absorption spectra}

The absorption spectra of the reagent NaPAR, the U(VI)-NaPAR complex formed in water solution and in the surfactant layer are provided in Fig. 1. The reagent NaPAR has a maximum absorption spectrum at $400 \mathrm{~nm}$, (Fig.1 a). On the other hand, the U(VI)-NaPAR complex formed in aqueous solution, (Fig. 1 b), had a maximum absorption spectrum at $530 \mathrm{~nm}$ that is completely different from that of the ligand NaPAR. Moreover, the absorbance of U(VI)-NaPAR complex formed in the HOL layer, (Fig.1 c), is much greater than that formed in the aqueous solution. These findings provide a good evidence of the role of the surfactant HOL in concentrating the U(VI)-NaPAR complex in the scum layer.

\section{Flotation of $U(V I)$}

Influence of hydrogen ion concentration

A number of experiments were performed 
to float $\mathrm{U}(\mathrm{VI})$ in the existence of HOL alone. A proper amount of U(VI), (2 x $\left.10^{-5} \mathrm{moll}^{-1}\right)$, was taken into the flotation cell along with an adequate amount of oleic acid surfactant $\left(2 \times 10^{-4}\right.$ moll $^{-}$ $\left.{ }^{1}\right)$ to float $\mathrm{U}(\mathrm{VI})$ over a wide $\mathrm{pH}$ range. The final results represented in Fig. 2 curve a, denotes how the flotation percentage is below $20 \%$ throughout the $\mathrm{pH}$ values used wherein the uranyl ions float as U(VI)-oleate towards the scum layer. Precisely the same experiments were performed in the existence of $2 \times 10^{-4}$ moll $^{-1} \mathrm{NaPAR}$ being a complexing agent. The results, Fig. 2 graph b, revealed that maximum and complete flotation $(\approx 100 \%)$ of $\mathrm{U}(\mathrm{VI})$ was gained within the 5-6 $\mathrm{pH}$ range.

\section{Influence of ligand and metal concentration}

The Influence of ligand and metal concentration is presented in Fig. 3 and 4, respectively.

From Fig. 3, it had been found out that the flotation $\%$ of U(VI) increases progressively with the increase in the ligand concentration until it reaches its maximum at $2 \times 10^{-5} \mathrm{moll}^{-1}$ at which $\mathrm{U}(\mathrm{VI})$ forms 1:1 complex with NaPAR. The flotation $\%$ remains constant upon further increase in ligand concentration. This finding allows an easy procedure to separate and determine U(IV) particularly in samples that contain unknown amounts of U(VI).

On the other hand, another number of experimental work was completed using a fixed amount of NaPAR, $2 \times 10^{-5}$ moll $^{-1}$, and changing the U(VI) concentration The results (Fig. 4) demonstrated that complete flotation was obtained at $2 \times 10^{-5} \mathrm{moll}^{-1}$ of $\mathrm{U}(\mathrm{VI})$. At that concentration $\mathrm{U}(\mathrm{VI})$ forms a 1:1 U(VI): NaPAR complex. When the U(VI) concentration was increased above such a ratio, the flotation $\%$ was decreased. This finding demonstrated that an adequate amount of the reagent NaPAR should be present to ensure complete complexation and hence subsequent flotation of $\mathrm{U}(\mathrm{VI})$ ions.

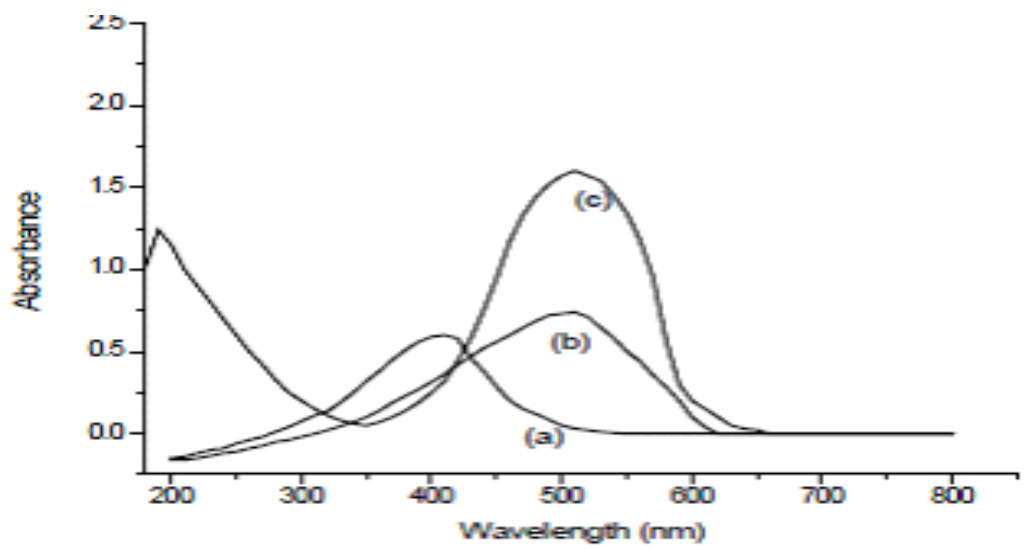

Fig. 1. Absorption spectra of: (a) The reagent NaPAR, (b) U*NaPAR system and (c) U*NaPAR-HOL system.

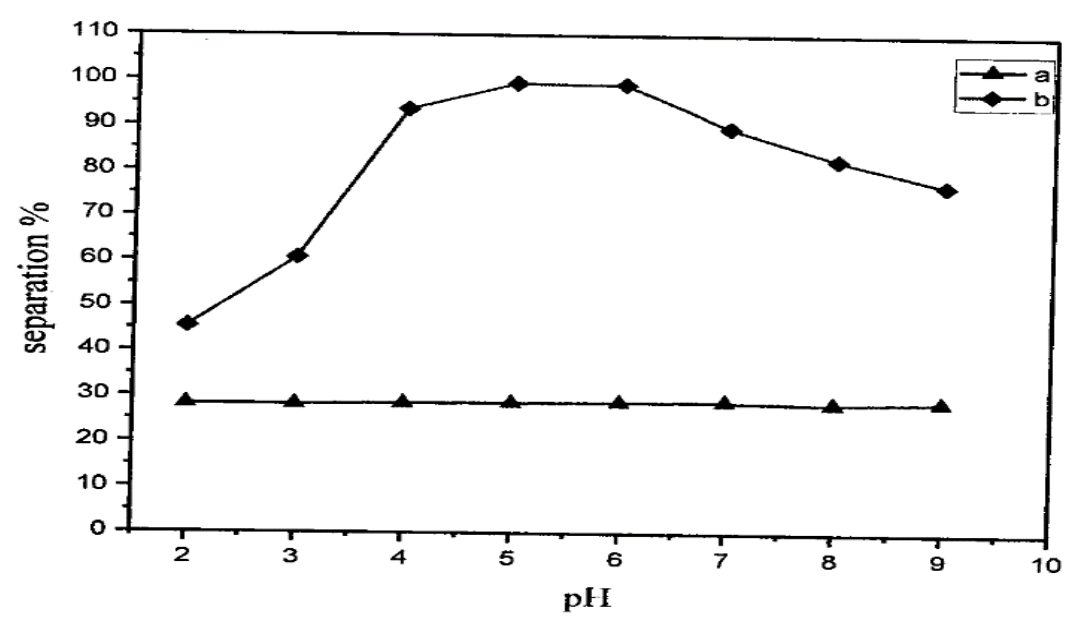

Fig. 2. The variation of separation $\%$ of $2 \times 10^{-5} \mathrm{moll}^{-1} \mathrm{U}(\mathrm{VI})$ with the $\mathrm{pH}$ values (a) in the absence of NaPAR (b) in the presence of $2 \times 10^{-4} \mathrm{moll}^{-1} \mathrm{NaPAR}$ using $2 \times 10^{-4} \mathrm{moll}^{-1}$ HOL.

Egypt. J. Chem. 61, No.2 (2018) 


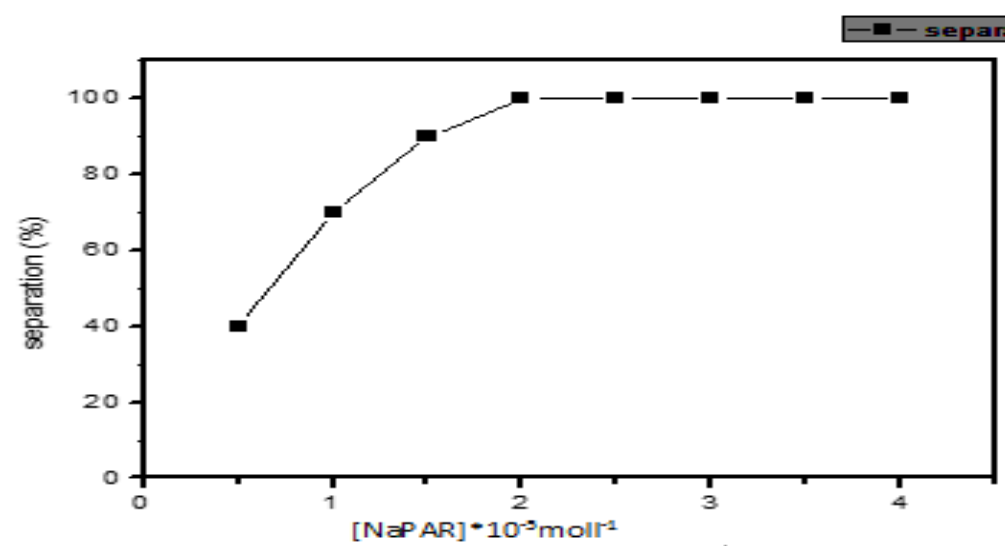

Fig. 3. The variation of separation $\%$ of $2 \times 10^{-5} \mathrm{moll}^{-1} \mathrm{U}(\mathrm{VI})$ with ligand concentration in the presence of $2 \times 10^{-4}$ moll-1 HOL a pH 6.

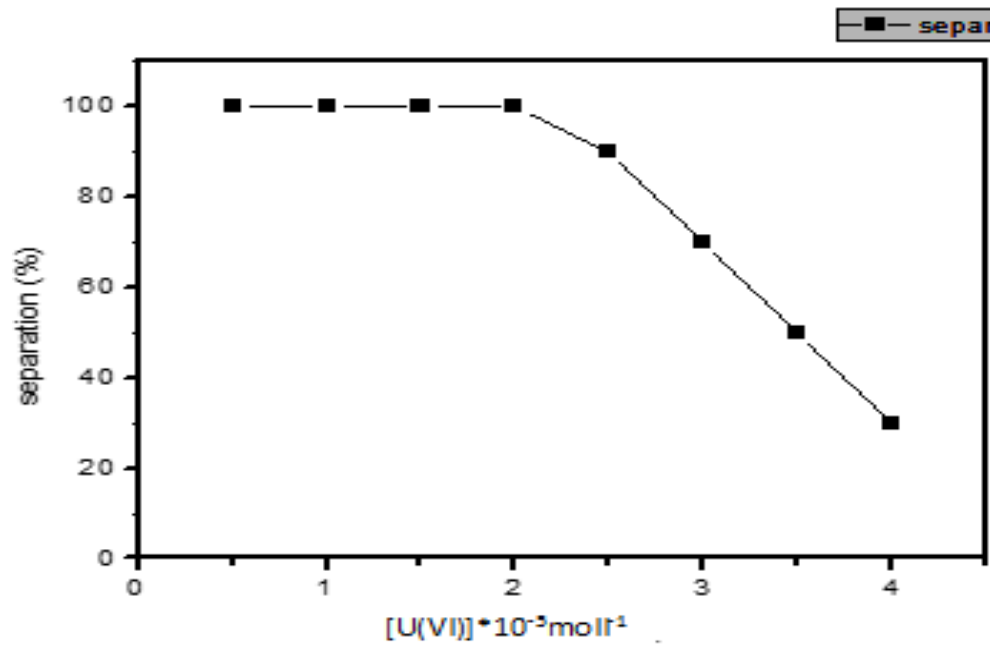

Fig. 4. The variation of separation $\%$ with different $\mathrm{U}(\mathrm{VI})$ concentration at $\mathrm{pH} 6.0$ in the presence of $2 \times 10^{-5} \mathrm{moll}^{-1}$ NaPAR using $2 \times 10^{-4} \mathrm{moll}^{-1} \mathrm{HOL}$ at $\mathrm{pH} 6.0$.

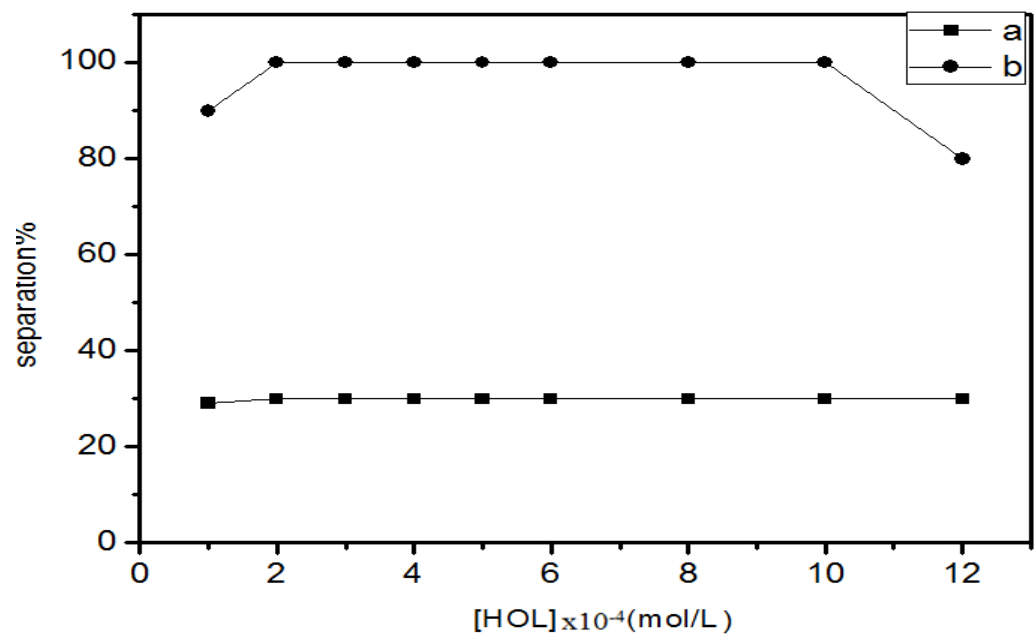

Fig. 5. The variation of separation $\%$ of $2 \times 10^{-5} \mathrm{moll}^{-1} \mathrm{U}(\mathrm{VI})$ with different $\mathrm{HOL}$ concentrations at $\mathrm{pH} 6.0$ (a) in the absence of NaPAR (b) in the presence of $2 \times 10^{-4} \mathrm{moll}^{-1} \mathrm{NaPAR}$. 
Influence of HOL concentration.

The flotation efficiency of U(VI) in the absence of NaPAR using different concentrations of HOL is demonstrated in Fig. 5, a. The Flotation \% doesn't exceed $20 \%$. On the other hand, maximum flotation $\%$ of U(VI) $100 \%$ was successfully obtained over large scale of HOL concentration $\left(2 \times 10^{-4}-1 \times 10^{-3}\right.$ mol l-1 in the use of $2 \times 10^{-4} \mathrm{~mol} \mathrm{l}^{-1}$ of NaPAR, (Fig. 5 , b). This finding clearly demonstrates the beneficial role of the ligand in the complexation and successful flotation of U(VI). An appropriate concentration of HOL $\left(2 \times 10^{-4} \mathrm{~mol} \mathrm{l}^{-1}\right)$ was utilized for subsequent experiments.

\section{Influence of temperature}

The proposed flotation technique was performed over $20-80{ }^{\circ} \mathrm{C}$. The results in Fig. 6, demonstrated that the maximum flotation of U(VI)-NaPAR complex wasn't markedly changed within the 20$80^{\circ} \mathrm{C}$. Subsequent experiments were performed at $25^{\circ} \mathrm{C}$.
Flotation time and stability of U(VI)-NaPAR complex within the scum layer

Flotation time could be defined as the interval time relating to the introducing of all reagents (U(VI), NaPAR, HOL and buffer) inside the flotation cell and the start of flotation. The effects of flotation time for the flotation efficiency of U(VI) was examined over a time period range of $0-60 \mathrm{~min}$ whilst the other parameters were kept constant. It had been found out that maximum flotation (F»100\%) could possibly be obtained within $2 \mathrm{~min}$, (Fig. 7). A time period of 5 min was chosen for additional experiments as the flotation time. Because of this, the flotation separation procedure isn't time consuming. As a way to confirm the stability of U(VI)-NaPAR complex after $5 \mathrm{~min}$, additional tests had been performed from 5 minutes to 72 hours. It had been demonstrated that the colour of floated U(VI)-NaPAR complex in the scum layer as well as the separation efficiency $\%$ didn't change approximately for $72 \mathrm{hr}$.

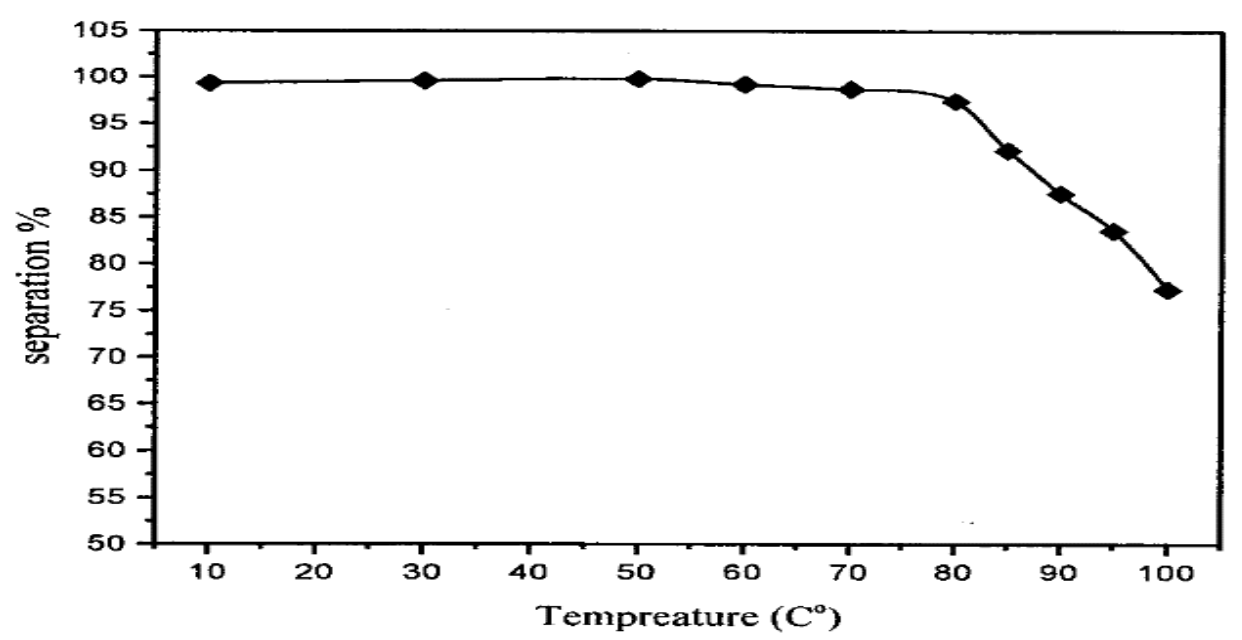

Fig. 6. The variation of separation $\%$ of $2 \times 10^{-5} \mathrm{moll}^{-1} \mathrm{U}(\mathrm{VI})$ with different temperature values using $2 \times 10^{-4} \mathrm{moll}^{-1}$ NaPAR in the presence of $2 \times 10^{-4} \mathrm{moll}^{-1} \mathrm{HOL}$ at $\mathrm{pH} 6.0$.

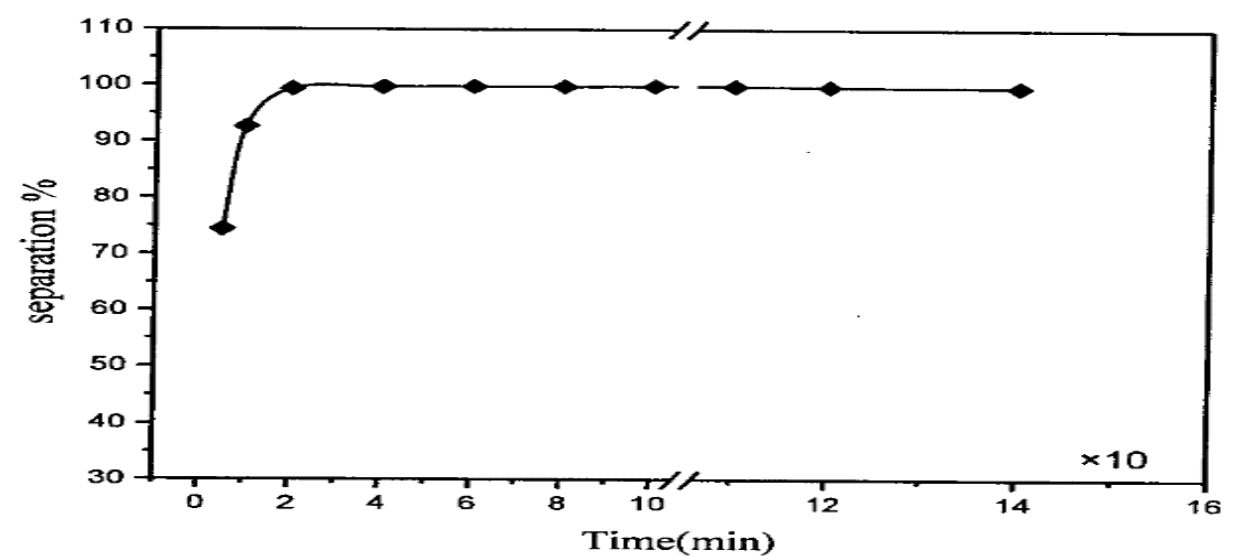

Fig.7.The variation of separation $\%$ of $2 \times 10^{-5} \mathrm{moll}^{-1} \mathrm{U}(\mathrm{VI})$ with the flotation time using $2 \times 10^{-4} \mathrm{moll}^{-1} \mathrm{NaPAR}$ in the presence of $2 \times 10^{-4} \mathrm{moll}^{-1} \mathrm{HOL}$ at $\mathrm{pH} 6.0$. 


\section{Influence of solution volume.}

Suitable large flotation cells have been used to float different concentrations of U(VI) from various aqueous volumes using the proposed technique. The results, Fig. 8, demonstrated that, as much as 100 ppm of U(VI) could possibly be completely separated into the HOL layer from $1000 \mathrm{ml}$ of sample solution into 10 $\mathrm{ml}$ of HOL. The preconcentration factor was calculated to be 100 .

Influence of diverse ions

The influence of diverse ions on the separation via flotation of $\mathrm{U}(\mathrm{IV})$ using NaPAR and HOL continues to be examined in details. Cations such as sodium(I), potassium(I), silver(I), calcium(II), magnesium(II), Sr(II), lead(II), cadmium(II) and Nickel(II) and anions like chlorides, sulphates or nitrates don't have any effect. Other cations like aluminum (III), mercury(II), iron(III), and vanadium(V) didn't have much interfering effects $(\sim 1 \%)$, Table 1. Most of these effects were totally eliminated with the addition of excess of the chelating agent $\operatorname{NaPAR}\left(2 \times 10^{-3} \mathrm{~mol} \mathrm{l}^{-1}\right)$.

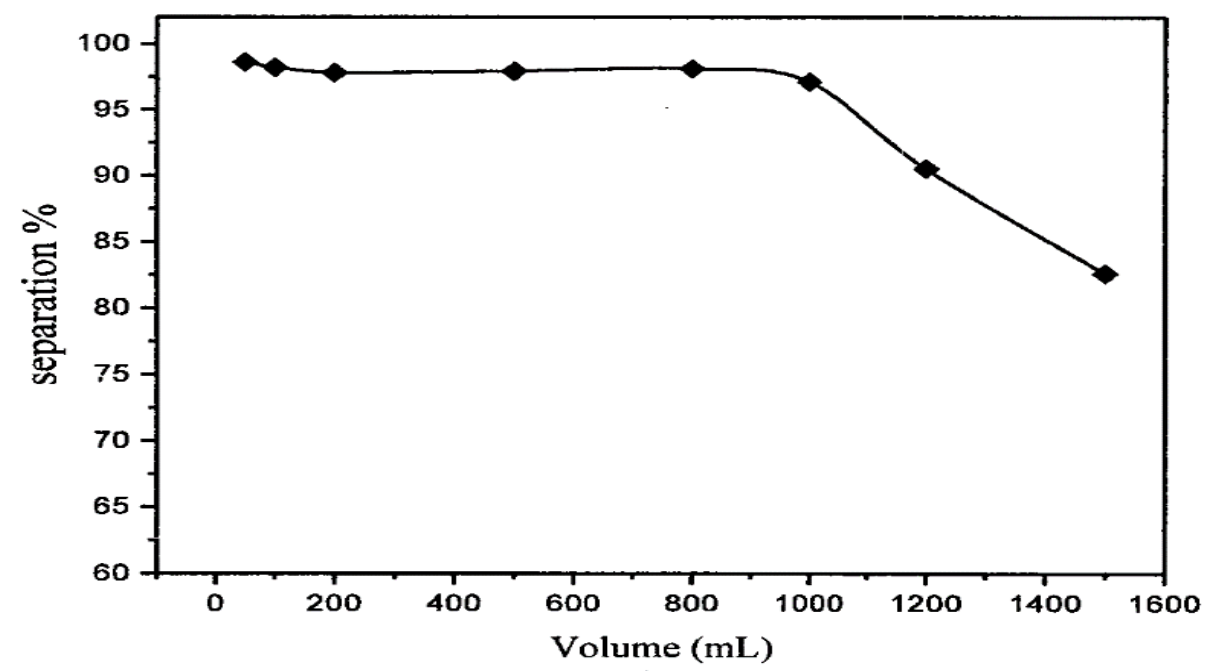

Fig. 8. The variation of separation $\%$ of $2 \times 10^{-5} \mathrm{moll}^{-1} \mathrm{U}(\mathrm{VI})$ with different solution volumes using $2 \times 10^{-4} \mathrm{moll}^{-1}$ NaPAR in the presence of $2 \times 10^{-4} \mathrm{moll}^{-1} \mathrm{HOL}$ at $\mathrm{pH}$ 6.0.

TABLE 1 . Effect of concentration of foreign ions on the recovery of $2.0 \times 10^{-5} \mathrm{moll}^{-1}$ of $\mathrm{U}(\mathrm{VI})$ using $2.0 \times 10^{-4} \mathrm{moll}^{-1}$ of NaPAR, $2.0 \times 10^{-4} \mathrm{moll}^{-1}$ HOL at pH $6(\mathrm{n}=5)$.

\begin{tabular}{|c|c|c|}
\hline Foreign ion & $\begin{array}{c}\text { Concentration } \\
(\mathrm{mg} / \mathrm{L}) \\
\end{array}$ & $\begin{array}{c}\text { Recovery\% } \\
\text { U(VI) }\end{array}$ \\
\hline $\mathrm{Hg}^{2+}$ & 50 & 99.6 \\
\hline $\mathrm{Fe}^{3+}$ & 50 & 96.8 \\
\hline $\mathrm{Cd}^{2+}$ & 50 & 99.8 \\
\hline $\mathrm{Cu}^{2+}$ & 50 & 98.8 \\
\hline $\mathrm{Co}^{2+}$ & 50 & 87.2 \\
\hline $\mathrm{Cr}^{3+}$ & 50 & 99.4 \\
\hline $\mathrm{Bi}^{3+}$ & 50 & 82.6 \\
\hline $\mathrm{Zn}^{2+}$ & 50 & 99.8 \\
\hline $\mathrm{Pb}^{2+}$ & 50 & 99.6 \\
\hline $\mathrm{Ni}^{2+}$ & 50 & 99 \\
\hline $\mathrm{Th}^{3+}$ & 50 & 99 \\
\hline $\mathrm{Mn}^{2+}$ & 50 & 85 \\
\hline EDTA & 01.0 & 46 \\
\hline $\mathrm{Na}_{2} \mathrm{CO}_{3}$ & 0.5 & 85 \\
\hline $\mathrm{Na}_{2} \mathrm{~S}_{2} \mathrm{O}_{3}$ & 0.5 & 98.2 \\
\hline $\mathrm{NaNO}_{2}$ & 0.5 & 99.8 \\
\hline
\end{tabular}

Egypt. J. Chem. 61, No.2 (2018) 


\section{Influence ionic strength}

The effect of ionic strength on the floatability of $2.0 \times 10^{-5} \mathrm{moll}^{-1}$ of U(VI) using $2.0 \times 10^{-4} \mathrm{moll}^{-}$ ${ }^{1}$ of NaPAR and $2.0 \times 10^{-4}$ moll $^{-1}$ HOL at $\mathrm{pH} 6$ is shown in Table 2. Different salts have been used for adjusting the ionic strength. As it can be noticed a marked flotation $\%$ could be obtained up to 010 moll $^{-1}$ of the used ionic strength adjustors.

\section{Physicochemical characteristics}

Various physicochemical characteristics are represented in Table 3 including the linear range, limits of detection as well as the limit of quantification, the relative standard deviation (RSD), the correlation coefficient (R2) and the preconcentration factor. Under optimum parameters, the proposed flotation procedures of U(VI), the following physicochemical characteristics were obtained. Beer's law was obeyed over $\quad 3.0-300 \mu \mathrm{g} \mathrm{l}^{-1}$ concentration range, the correlation coefficient $\left(\mathrm{R}^{2}\right)$ was calculated to be $\mathrm{R}^{2}=0.9995$. According to IUPAC recommendations, the limit of detection (LOD) and limit of quantification (LOQ) were calculated to be 0.9 and $3.1 \mathrm{~g} \mathrm{~g}^{-1}(n=5)$, respectively. The molar absorptivity $(\mathcal{E})$ is $0.63 \times 10^{6} 1 \mathrm{~mol}^{-1} \mathrm{~cm}^{-1}$ with a preconcentration factor 100 and the $\operatorname{RSD}(n=5)$ is $2.5 \%$. The precision of the flotation method for uranium(VI) was determined by repeatability (intra-day) and intermediate precision (inter-day). Intra-day precision was evaluated by assaying samples at the same concentration and on the same day. Five sample solutions $\left(100 \mu \mathrm{g} \mathrm{ml} \mathrm{m}^{-1}\right)$ were prepared and examined. The intermediate precision was studied by comparing the assays on different days (three days). The inter day and intra-day precision were calculated and showed a RSD of 0.58 and $0.98 \%$, respectively.

TABLE 2. Effect of different ionic strengths on the recovery of $2.0 \times 10^{-5} \mathrm{moll}^{-1}$ of U(VI) using $2.0 \times 10^{-4} \mathrm{moll}^{-1}$ of NaPAR, $2.0 \times 10^{-4} \mathrm{moll}^{-1} \mathrm{HOL}$ at $\mathrm{pH} 6$.

\begin{tabular}{lcc}
\hline Ionic strength $\left(\mathbf{m o l l}^{-1}\right)$ & Adjuster & Recovery \% \\
\hline & $\mathrm{NaCl}$ & 99.7 \\
0.10 & $\mathrm{Na}_{2} \mathrm{SO}_{4}$ & 95.0 \\
& $\mathrm{NaNO}_{3}$ & 90.6 \\
0.01 & $\mathrm{NaCl}^{2}$ & 94 \\
& $\mathrm{Na}_{2} \mathrm{SO}_{4}$ & 85.4 \\
& $\mathrm{NaNO}_{3}$ & 95 \\
0.05 & $\mathrm{NaCl}^{2}$ & 92.4 \\
& $\mathrm{Na}_{2} \mathrm{SO}_{4}$ & 95.8 \\
0.001 & $\mathrm{NaNO}_{3}$ & 93.4 \\
& $\mathrm{NaCl}^{*}$ & 99.6 \\
\hline
\end{tabular}

TABLE 3. Physicochemical characteristics of U(VI)-NaPAR complex.

\begin{tabular}{|c|c|}
\hline Characteristic & UO, $_{2}$ II)-NaPAR complex \\
\hline$\lambda_{\max }, \mathrm{nm}$ & 530 \\
\hline $\mathrm{pH}$ range & $5.0-6.0$ \\
\hline Linear range, $\mu \mathrm{g}^{-1}$ & $3.0-300$ \\
\hline Sandell's sensitivity, $\mu \mathrm{g} \mathrm{cm}^{-2}$ & 0.0125 \\
\hline Molar absorptivity $(\mathcal{E}), 1 \mathrm{~mol}^{-1} \mathrm{~cm}^{-1}$ & $0.63 \times 10^{6}$ \\
\hline Composition (M:L) by Job's method & $1: 1$ \\
\hline Limits of detection, $\mu \mathrm{g} \mathrm{l}^{-1}$ & 0.80 \\
\hline Limits of quantification, $\mu \mathrm{g} \mathrm{l}^{-1}$ & 2.70 \\
\hline Relative standard deviation (RSD), $\%$ & 2.50 \\
\hline Correlation coefficient $\left(\mathrm{R}^{2}\right)$ & 0.9995 \\
\hline Preconcentration factor & 100 \\
\hline RSD, \% & 2.5 \\
\hline
\end{tabular}




\section{Applications}

The proposed flotation technique had been used to determine U(VI) in various real ore, granite and waters samples. The results for natural water samples are given in Table 4. As it can be seen, the recovery of the added $\mathrm{U}(\mathrm{VI})$ reached about $95 \%$ in all samples. On the other hand, the results for $\mathrm{U}$ Th ore and granite ore samples presented in Table 5, provide good evidence for the suitability and applicability of the proposed methodology for preconcentration and spectrophotometric determination of uranyl ion from real samples, depending on the good agreement between the determined and assigned standard composition of the examined ores. The calculated $|\mathbf{t}|$, values are below the hypothetical $|\mathfrak{t}|_{1}$ value (2.78) for $\mathrm{P}=$ 0.05 and $n=5$ (4 degree of freedom). Statistical analysis of the results in Table 5 indicates that the preconcentrated samples are not subject to any systematic error i.e. accurate.

\section{Flotation Mechanism}

The mechanism of flotation of U(VI) using the NaPAR chelating agent and the HOL surfactant might be attributed to the formation of a hydrogen bonding between the hydrophilic part of HOL and the active sites in the U(VI)-NaPAR chelate. This proposal has been concluded from the following findings: 1) the complex formed in scum layer has the same red color as the complex formed in the aqueous solution; 2) The colour intensity and absorbance of the scum layer were not affected by heating up to $80^{\circ} \mathrm{C}, 3$ ) The infrared spectra of the U(VI)NaPAR complex formed in the DDW is completely different from the U(VI) NaPAR complex formed in presence of oleic acid surfactant (Fig. 9).

TABLE 4. Recovery of U(VI) spiked in natural water samples after flotation using 2x10-4 moll-1 NaPAR and 2.0 $x$ 10-4 moll-1 HOL at $\mathrm{pH} \sim 6$ at $25^{\circ} \mathrm{C}$.

\begin{tabular}{lccc}
\hline Type of water & U(VI) added $\left(\mathbf{m g l}^{-\mathbf{1}}\right)$ & Recovery $\%$ & RSD \% \\
(location) & 1.00 & 98.6 & 0.42 \\
\hline \multirow{2}{*}{ Distilled water } & 3.00 & 98.5 & 0.56 \\
& 5.00 & 99.7 & 0.78 \\
Tap water & 1.00 & 97.4 & 0.62 \\
& 3.00 & 98.9 & 1.12 \\
(our lab) & 5.00 & 99.3 & 1.41 \\
Nile water & 1.00 & 95.6 & 0.38 \\
& 3.00 & 94.9 & 0.74 \\
(EL-Mahalla city) & 5.00 & 93.8 & 1.18 \\
Sea water & 1.00 & 99 & 1.05 \\
& 3.00 & 99.2 & 1.35 \\
(Alexandria city) & 5.00 & 99.9 & 1.74 \\
Well water & 1.00 & 99.5 & 1.48 \\
Anter city) Meet) & 3.00 & 99.3 & 0.94 \\
\hline
\end{tabular}

TABLE 5. Statistical evaluation for analysis of $U(V I)$ in some certified ore samples using the proposed flotation technique(n=5). Comparison of experimental mean $(\bar{X})$ with true value 0 by $|t|_{1}$ test

\begin{tabular}{|c|c|c|c|}
\hline Ore Sample & $\begin{array}{c}\mathrm{X} \\
\text { (Exp. Value) } \\
\end{array}$ & (Standard value) & $|\mathbf{t}|_{1}$ \\
\hline U-Th ore $(206$ ADL $1 \mathrm{~A}) *$ & 0.0080 .03 & $0.012 \%$ & 2.23 \\
\hline U-Th ore $(206 \mathrm{ADH} 1 \mathrm{~A}) *$ & 0.2680 .02 & $0.263 \%$ & 2.1 \\
\hline $\mathrm{U}$ ore $(206 \mathrm{ABL} 2 \mathrm{~A}) *$ & $0.430 \quad 0.05$ & $0.426 \%$ & 1.12 \\
\hline Granite (I) (MALI MINTEK GRANITE: NIM. G.) & 14.51 .3 & $15 \mathrm{ppm}$ & 1.90 \\
\hline Granite (II)(83 MALS MINTEK LUJAVRITE NJM. I.) & 13.70 .8 & $14 \mathrm{ppm}$ & 2.5 \\
\hline
\end{tabular}

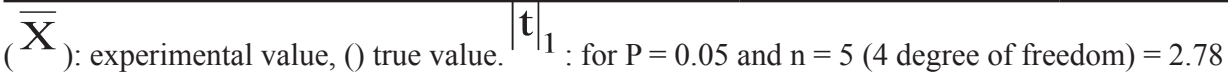

* Concentration of uranium, $\%$.

Concentration of uranium, ppm.

Egypt. J. Chem. 61, No.2 (2018) 


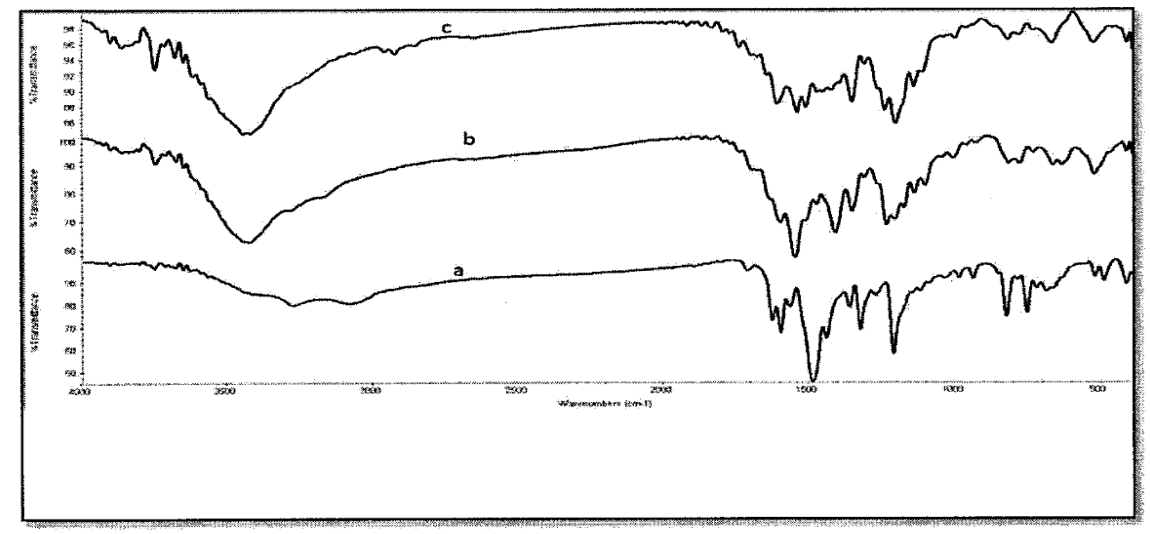

Fig. 9. Infrared spectra of a) NaPAR, b) U(VI) $\cdot \mathrm{NaPAR}$ complex isolated in aqueous solution and c) U(VI) $\cdot \mathrm{NaPAR}$ complex isolated in oleic acid.

\section{Conclusion}

The proposed flotation is a simple technique using a simple flotation cell. The method is advantageous to many of the separation techniques previously reported for the spectrophotometric determination of U(VI). The method has increased molar absorptivity value and law detection limit. It is sensitive, accurate, and can accommodate different foreign ions. The use of large flotation cells allowed the determination of $\mathrm{U}(\mathrm{VI})$ from water samples having large volume with a high preconcentration factor. The sensitivities of various spectrophotometric reagents known for $\mathrm{U}(\mathrm{VI})$ are given in Table 6. As it can be noticed the present combined flotation - spectrophotometric methodology has a good sensitivity for the micro determination of U(VI) compared to the previously reported procedures. Thus, the present study introduces a simple and low cost instrumental method like UV-Vis spectrophotometer to analysis of environmental and certified ore samples containing trace amounts of U(VI)

\section{References}

1. Lehto, J. and Hou, X., Chemistry and Analysis of Radionuclides: Laboratory Techniques and Methodology. Wiley-VCH Verlag GmbH \&. K Ga A, Weinheim (2010).

2. Wen, T.Y., Du J.Z., Ji T., Wang X.L., Deng B., Use of $222 \mathrm{Rn}$ to trace submarine ground water discharge in a tidal period along the coast of Xiangshan, Zhejiang, China. J. Radioanal. Nucl. Chem. 299(1), 53(2014).

3. Christl M., Lachner J., Vockenhuber C.,
Lechtenfeld O., Stimac I., van der Loeff MR, Synal H-A., A depth profile of uranium 236-in the Atlantic Ocean. Geochim Cosmochim Acta 77, 98-107(2012).

4. Ku, T-L., Knauss, K.G., Mathieu, G.G., Uranium in open ocean: concentration and isotopic composition., Deep Sea Res 24(11), 1005-1017 1977).

5. Palmer, M.R., Edmond, J.M., Uranium in river water. Geochim Cosmochim Acta 57(20),49474955(1993).

6. Brits, R.J.N. and Smit, M.C.B., Determination of uranium in natural water by preconcentration on anion-exchange resin and delayed-neutron counting, Anal Chem 49(1), 67-69(1977).

7. Al Ammar, A.S. and Basheer H.M., Further development in the high-precision volumetric method for the determination of uranium in nuclear-grade uranium compounds, $J$ Radioanal Nucl Chem 171 (2), 435-441(1993).

8. Mlakar, M., Branica, M., Stripping voltammetric determination of trace levels of uranium by synergic adsorption, Anal Chim Acta, 221, 279 (1989).

9. Korkisch, J. and Godl, J., Determination of uranium in natural waters after anion-exchange separation, Anal Chim Acta 71,113-121(1974).

10. Hong, K.B., Jung, K.W., Jung, K.H., Application of laser-induced fluorescence for determination of trace uranium, europium and samarium, Talanta 36,1095(1989).

11. McMahon, A.W., Application of analytical methods based on X-ray spectroscopy to the

Egypt. J. Chem. 61, No.2 (2018) 
determination of radionuclides, Sci Total Environ 130, 285(1993).

12. Perez Pavon, J.L., Moreno, C. B., Rodriguez Garcia, E., Hernandez Mendez, J., Determination of uranium using a flow system with reagent injection. Application to the determination of uranium in ore leachates, Anal Chim Acta 230, 217(1990).

13. Jianhua, W., Ronghuan, H. A., Kinetic Spectrophotometric Method for Simultaneous Determination of Uranium, Iron and Vanadium with a Stopped-Flow Technique. Chem Anal (Warsaw) 38, 497(1993).

14. Prakash, O., Kumar, S., Mushran, S.P., Sensitive spectrophotometric method for trace amounts of uranium, Talanta 26,1167-1169 (1979).

15. Truscott, J.B., Bromley, L., Jones, P., Evans, E.H., Turner, J., Fairman, B., Determination of natural uranium and thorium in environmental samples by ETV-ICP-MS after matrix removal by on-line solid phase extraction., J Anal At Spectrom 14, 627-631(1999).

16. Dadfarnia, S., Mcleod, C.W., On-Line Trace Enrichment and Determination of Uranium in Waters by Flow Injection Inductively Coupled Plasma Mass Spectrometry. Appl Spectrosc 48,1331(1994).

17. Horwiz, E.P., Dietz, M.L., Chiariza, R., Diamond, $\mathrm{H}$., Separation and preconcentration of uranium from acidic media by extraction chromatography. Anal.Chim Acta 266, 25-37(1992).

18. Deorkar, N.V., Khopkar S.M., Separation of uranium(VI) as chloride complex by solvent extraction with dicyclohexyl-18-crown-6. J Radioanal Nucl Chem130, 433-441(1989).

19. Birdwell, J.F. uranium extraction selectivities of dibutyl carbitol and tributyl phosphate in the system $\mathrm{UO}_{2}\left(\mathrm{NO}_{3}\right) 2-\mathrm{HNO}_{3} \mathrm{H}_{2} \mathrm{O}-\mathrm{Al}\left(\mathrm{NO}_{3}\right)_{3}$-solvent. Sep Sci Technol 34, 987-1006 (1999).

20. Lee, C.H., Suh, M.Y., Kim, J.S., Kim, D.L., Kim, W.H., Eom, T.W., Separation and preconcentration of uranium from geological materials with chelating resin containing 4-(2-thiazolylazo) resorcinol functional groups, Anal Chim Acta 382,199-203(1999).

21. Sundardmurthi, M.M., Shinde, U.M. Extraction and separation of uranium and lead with liquid anion-exchangers Talanta 38, 223(1991).
22. Kadyan, P. S., Garg, S., Singh, D. and Verma, S. Selective Determination of Uranium Using 1-(2-Quinolylazo)-2,4,5-Trihydroxybenzene as a Colorimetric Reagent, Chem Sci Trans., 2(2), 435440 (2013).

23. Ghazy, S.E., Kabil, M.A., Determination of Trace Copper in Natural Waters after Selective Separation by Flotation. Bull Chem. Soc. Jpn. 67, 2098 - 2102 (1994).

24. Kabil, M.A., Akl, M.A., Khalifa, M.E., Selective Flotation Spectrophotometric Procedure for trace Analysis of Palladium in different matrices. Anal Sci 15, 433-438 (1999).

25. Kabil, M.A., Akl, M.A., Abdallah, A.M., Ismael, D. Selective Separation-Flotationof Hafnium from Zirconium and their determination in real samples. Anal Sci 16,713-718 (2000).

26. Khalifa, M.E., Akl, M.A., Ghazy, S.E., Selective Flotation-Spectrophotometric Determination of Trace Copper (II) in Natural Waters, Human Blood and Drug Samples using Phenanthraquinone Monophenylthiosemicarbazone. Chem Pharm Bull (Japan) 49, 664-668(2001).

27. Akl, M.A., Kabil, M.A., Abdallah, A.M., Ismael, D., Use of Eriochrome CyanineR (ECR) for Separation-Flotation and micro determination of Hafnium and Zirconium in real Samples. Sep Sci and Tech (USA) 36, 2747-2760 (2001).

28. Akl M.A., Khalifa M.E., Ghazy S.E., Hassanien M.M. Selective flotationseparationand spectrophotometric determination of cadmium using phenanthraquinone monophenyl thiosemicarbazone, Anal Sci 18, 1235-1240 (2002).

29. Akl, M.A., Kabil, M.A., Abdalla, A.M., Ismael, D.S., Flotation and sectrophotometry: Thorough investigation and application to the spectrophotometric determination of the total amounts of lanthanum and yttrium in natural samples. Bull Chem Soc Jpn 76,1543 (2003) .

30. Abdalla, A.M., Kabil, M.A., Ak1, M.A., Ismael, D.S., Simultaneous preconcentration flotation separation and spectrophotometric determination of thorium, lanthanum and yttrium in some geological and environmental samples. JICS 1, 79 (2004).

31. Akl, M.A., El-Asmy, A.A., Yossef, W.M., Separation via flotation, spectrophotometric speciation, and determination of vanadium(IV) in wastes of power stations. Anal Sci 21, 1325-1335 
(2005).

32. AK1, M.A., Ismael, D.S., Elasmy, A.A., Precipitate Flotation-Separation speciation and Hydride Generation Atomic Absorption Spectrometric Determination of Selenium(IV) in Food Stuffs. Microchemical Journal (USA) 83,61-69(2006).

33. Akl, M.A., The Use of Phenathraquinone Monophenyl Thiosemicarbazone for Preconcentration, Ion flotation and Spectrometric Determination of Zinc(II) in Human Biofluids and Environmental Samples. Bulletin of the Korean Chemical Society (South Korea) 27, 725 (2006).

34. El-Asmy, A.F.A., Yousef,W.M., Akl, M.A., Flotation Speciation and determination of iron(III) using aluminon in water, real samples and wastes of power stations. European Journal of Chemistry 1, 189-194 (2010).

35. Akl, M. A., Isamil, D.S., Jeragh, B., El-Asmy, A. A., Flotation separation and spectrophotometric determination of $\mathrm{Sc} 3+$ in certified materials and different water resources. Journal of Scientific Research and Reviews 3,008-017(2014).

36. Marczenko, Z. Separation And Spectrophotometric Determination of Elements, 2nd ed. Ellis Horwood, London (1986).

37. Rao, M. R., Hari, K., Devanna, N. and Chandrashekhar, K. B., Derivative Spectrophotometric Determination of Uranium(VI) using 2-Hydroxy-3-methoxbenzaldehydeisonicotin oylhydrazone. Reagent Asian J Chem., 20(2), 1402 (2008).

38. Teixeira, L. S. G., Costa, A. C. S., Ferreira, S. L. C., Freitas, M. D. L. and Carvalho, M. S. D, Spectrophotometric Determination of Uranium Using 2-(2-Thiazolylazo)-p-Cresol (TAC) in the Presence of Surfactants, J Braz Chem Soc., 10(6), 519 (1999).
39. Park, C. I., Huang, H. Z. and Cha, K. W., Spectrophotometric Determination of Uranium(VI) with Pyrocatechol Violet in Surfactant Media. Bull Korean Chem. Soc. 22(1),84 (2001).

40. Agnihotri, N. K., Singh, V. K. and Singh, H. B., High-order derivative spectrophotometric determination of uranium in a cationic micellar medium. Analyst,120, 1809-1814 (1995).

41. 42. Verma, S., Garg, S. and Kadyan, P. S., Spectrophotometric Determination of Uranium Using Tris-[2,4, 6-(2-hydroxy-4-sulpho-1naphthylazo)]-striazine, Trisodium Salt (THT), Chem Sci Trans., 3(1), 61-66 (2014).

42. Reddy, G. C., Devanna, N. and Chandrasekhar, K. B., Derivative spectrophotometric determination of uranium (VI) using diacetyl monoxime isonicotinoyl hydrazone (DMIH), Orbital Elec $J$ Chem., 3(1), 24 (2011).

43. Saran, R. and Baishya, N. K., Direct, derivative and simultaneous spectrophotometric methods of determination of Iron(II) and Uranium(VI) in various environmental, biological and ore samples J Radioanal Nucl Chem., 196, 363(1995).

44. Agrawal, Y. K. Shrivastav, P. and Menon, S. K., Extraction, separation of uranium(VI) with crown ether, Sep Purif Technol., 20, 177-183(2000).

45. Vijaya Kumari, D. and Lakshiminarayana, K., A sensitive spectrophotometric method for the determination of trace amounts of uranium(VI) using 2-hydroxy-1-naphthaldehyde isonicotinoyl hydrazine, J Radioanal Nucl Chem., 175,1-7(1993).

46. Abu-Eid, M., Zatar, N. A., Al-Nuri, M. A., Khamis, M., Hannoun, M. and Khalaf, S., "Spectrophotometric Determanation of Uranium with Di2-Pyridyl Ketone Benzoylhydrazone. An-Najah J Res., 2(8) 72(1994).

(Received 20/1/2018; accepted 13/2/2018) 


\section{التعويم وتحسين التقدير الطيفي لليورانيوم السداسي في العينات البيئية

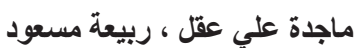 \\ قسم الكيمياء، كلية العلوم، جامعة الدنصورة ، مصر.}

تم عرض تقنتة خضر اء وبسيطة للفصل عن طريق التعويم والتحليل الطيفي لليور انيوم السداسي في عينات المياه

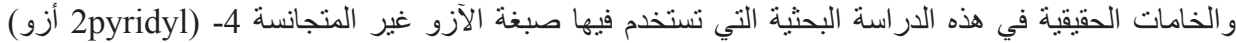

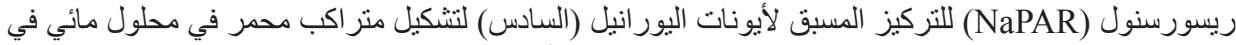

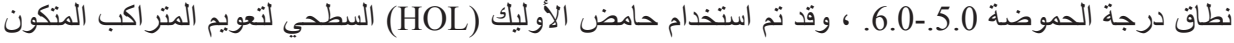

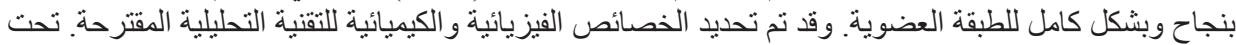

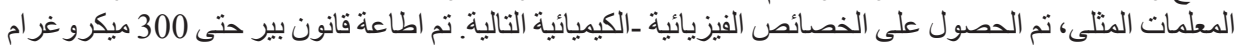

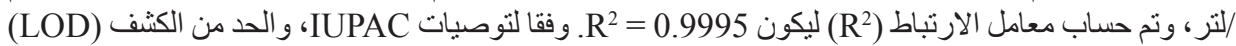

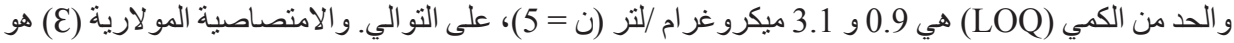

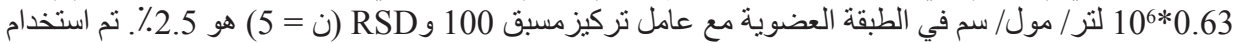

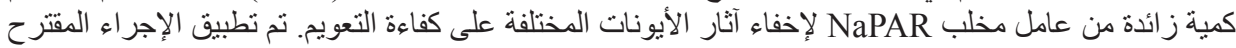

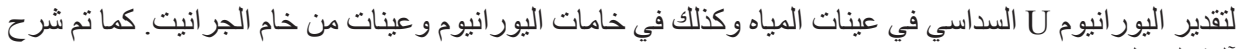

